\title{
The potential of a sustainable municipal waste management system for Santiago de Chile, including energy production from waste
}

\author{
Tahnee González Martínez ${ }^{1 *}$, Klaus-Rainer Bräutigam ${ }^{2 *}$ and Helmut Seifert ${ }^{2}$
}

\begin{abstract}
Background: Due to a rapid urbanization process in the Metropolitan Region of Santiago de Chile (MRS), the amount of municipal solid waste (MSW) generated has increased considerably within the last years. MSW should be managed properly in order to achieve sustainable development. The purpose of this study is to analyze MSW management in MRS on the basis of three different explorative scenarios for the year 2030.

Methods: The Integrative Sustainability Concept of the Helmholtz Association provided a conceptual framework for the study and was used to evaluate the scenarios. One important topic within the field of management of MSW in the year 2030 will be the contribution of waste treatment technologies to energy production, e.g., by the use of landfill gas and by separated collection of biowaste followed by anaerobic treatment.

Results: The largest sustainability deficits in the scenarios are the small proportion of MSW being pre-treated before final disposal and the greenhouse gas (GHG) emissions associated with MSW disposal. MSW management technologies taken into consideration were mechanical biological treatment, energy recovery from MSW in anaerobic digestion plants with biogas production, the production of refuse-derived fuel and its use as a secondary fuel, as well as electricity generation from landfill gas. Energy generation from MSW in 2030 will be about $6 \%$ of electricity consumption in 2010.

Conclusions: The three scenarios show some sustainability deficits. Even so, there are some improvements such as the reduction of GHG emissions and - even though marginal - energy supply for MRS from renewable energy sources.
\end{abstract}

Keywords: Waste management, Scenarios, Sustainability, Megacities, Energy from waste

\section{Background}

Adequate management of municipal solid waste (MSW) is essential for the health of urban residents, for the protection of the environment and the conservation of resources, and therefore for the sustainability of any city. In its widest sense, the activities associated with the management of MSW include waste handling, collection and transport, treatment, recovery of materials and energy, and final disposal (Figure 1). In most developed countries, each of these stages, mainly due to legal regulations, occurs as part of the system.

\footnotetext{
* Correspondence: tahnee.gonzalez.martinez@linde-le.com; klaus-rainer.braeutigam@kit.edu

'Linde AG Engineering Division, Dr.-Carl-von-Linde-Str. 6-14, Pullach, München 82049, Germany

Full list of author information is available at the end of the article
}

In Germany, the amount of waste disposed of has been reduced considerably within the last years due to the fact that since 2005 the landfilling of untreated waste is no longer allowed. Instead, mechanical, biological, and/or thermal treatment measures have to be carried out before final disposal. This is the result of a planned waste management strategy initiated by the Government more than 20 years ago [2], of which the fundamental objectives are (a) the reduction of waste generation, (b) the prohibition of uncontrolled discarding, discharge, and disposal of waste, and (c) the promotion of integrated waste management systems following the steps: avoidance, recycling, and conversion of waste with a preference to material and energy recovery [2].

\section{空 Springer}




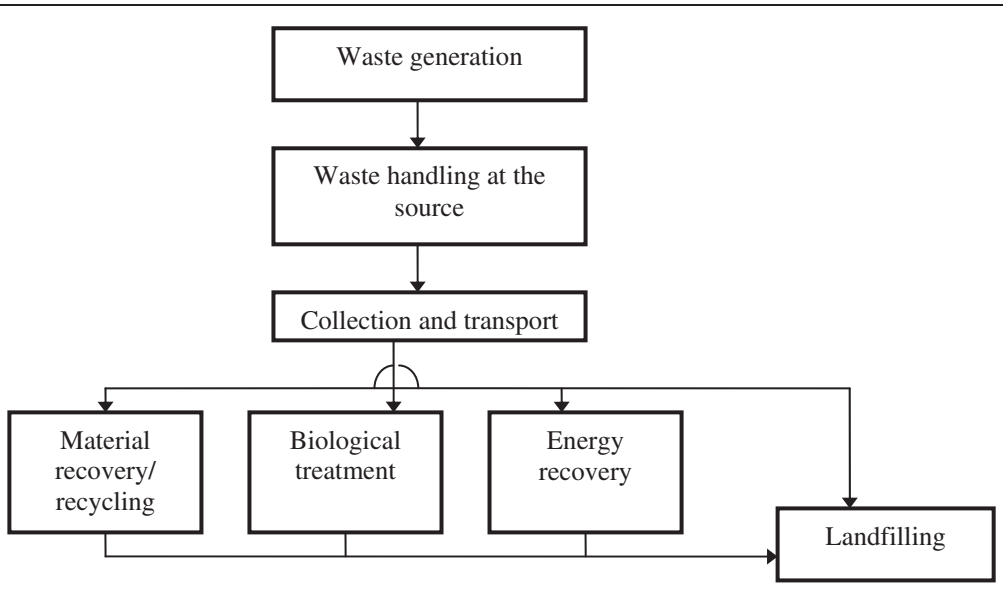

Figure 1 Stages in the solid waste management process (adapted from [1]).

The regulations governing waste management in Germany have led to a reduction of waste produced in recent years, decoupling economic development and waste production, in addition to a reduction of greenhouse gas emissions associated with MSW management. Currently, more than $60 \%$ of MSW is recovered; if energy recovery processes are included, the figure rises to around $95 \%$ [3]. Moreover, the increase in waste recovery is reflected in savings of fossil fuels such as oil, gas, and coal. Electricity production in Germany in 2011 accounted for $615 \mathrm{TWh}$. The share of renewable energies was $20 \%$, with $7.6 \%$ coming from wind power, $3.2 \%$ from hydropower, $3.1 \%$ from photovoltaic, and $6 \%$ from different kinds of biomass, which includes a share of $0.8 \%$ coming from energetic utilization of waste [4]. Electricity generation from the use of landfill gas in 2011 was less than $0.1 \%$ [5].

In most Latin American countries, the MSW management system is in the best case limited to handling at the source, collection, and disposal at landfills without any pre-treatment [6]. Energy recovery from MSW in Latin America is almost nonexistent. To date, the costs of incineration are far too high for local governments to consider it as an appropriate solid waste management technology [6]. There have been a few experiences with anaerobic digestion in Colombia and Costa Rica [7] but mainly for the treatment of wastewater from agricultural residues. There are some examples where mechanical biological treatment (MBT) has been applied successfully in Latin America, including experiences in Mexico, Brazil, and Chile [8-10]. In most of these cases, the informal waste pickers are the moving power in salvaging recyclable materials.

The Metropolitan Region of Santiago de Chile (MRS) is a typical Latin American megacity, showing population growth over the last years as well as a rising standard of living, associated with an increase of the gross domestic product (GDP) from US\$10,000 to US $\$ 14,000$ per capita in about 10 years. As a consequence, the amount of MSW produced also increased significantly. The high population density and good infrastructure allow for a very effective waste collection system, whereby nearly $100 \%$ of the households have access to collection services. Approximately $90 \%$ of the MSW generated is deposited in sanitary landfills. Due to particular characteristics of waste management in low- and middle-income countries $[11,12]$, most of the recycling market is dominated by the informal waste economy, constituted by primary collectors and middlemen [13].

Moreover, the urbanization process in MRS has also increased its energy demand. Electricity supply for MRS is highly dependent from electricity production outside MRS [14], and only about $25 \%$ of its demand is produced by power plants within the city. Electricity consumption in 2010 was about 17 TWh; $50 \%$ of the production in MRS came from different hydropower plants, and the other half from a combined cycle gas power station. Energy recovery from MSW in MRS from captured landfill gas is so far only realized in the Central Loma Los Colorados I station with an installed capacity of $2 \mathrm{MW}$. Within the planned phase II, the capacity will be extended to $14 \mathrm{MW}$, and an additional expansion to reach $28 \mathrm{MW}$ is planned for the year 2024 [15].

According to [16], each region should determine how much it is able to spend in MSW management in order to design its management system according to its economical capacity considering at the same time the preservation of human health, conservation of resources, and the environment. Germany and Chile differ largely in their GDP, and the German solid waste management system is highly advanced compared with the Chilean one.

Summarizing, although health and environmental problems arising from inadequate MSW management are 
well known, Chile, as well as most Latin American countries, has not set enough value into adequate MSW management [17] nor has the development of services related to waste management and its energy recovery received sufficient attention. Against this background, it seems to be a big challenge to find sustainable solutions to handle the large amounts of MSW generated. This article firstly presents the evaluation of different practices of treatment, recovery, and disposal of MSW for Santiago de Chile for three different scenarios for the year 2030 based on the Integrative Sustainability Concept of the Helmholtz Association. Based on this background, the following research questions arise:

1. For the evaluation and comparison of different MSW management systems, the Integrative Helmholtz Sustainability Concept (IHSC) was applied. How can this concept be contextualized to the field of MSW management, what are the most relevant sustainability indicators applicable to this field, and what are their appropriate target values?

2. What are possible development paths of MSW management in MRS for the next 20 years?

3. What technical options could improve the sustainability (e.g., in terms of GHG emissions and substitution of fossil fuels) of the MSW management system?

\section{Methods}

In order to describe and evaluate the current and the future MSW management system in MRS, the methodological approach was divided into five subsections, starting with a description of the sustainability evaluation, which includes an introduction into the IHSC and its application to the field of MSW management. Secondly, the setup of explorative scenarios is explained, in addition to a description of the relevant characteristics for MSW management of the Business as Usual (BAU), Collective Responsibility (CR), and Market Individualism (MI) scenarios. After these more theoretical explanations, the calculation procedure for waste generation in the three scenarios ('Waste generation' section) as well as the procedure for the selection of MSW management technologies ('Selection of MSW management technologies for the different scenarios' section) is presented. Based on this background information, possible energy production from MSW management in the three scenarios was calculated ('Calculation of energy production from MSW' section).

\section{Sustainability evaluation}

Within the Risk Habitat Megacity Project ${ }^{\mathrm{a}}$ [14], which had been accomplished in the years 2007 to 2010 and which had been supported by the 'Initiative and Networking Fund' of the Helmholtz Association [17,18], the IHSC was chosen as an appropriate tool for the comparison and evaluation of different technological development pathways, and the IHSC was also assigned to the field of management of MSW. Contrary to most sustainability concepts, the basic idea here is to avoid defining sustainable development along 'classic' economic, ecological, and social lines. Instead, the IHSC begins with the constitutive elements of the sustainability overall concept, derived from key documents such as the Brundtland Report, the Rio Declaration, and Agenda 21: (a) the postulate of inter- and intragenerational justice, (b) the global perspective, and (c) the anthropocentric view [19-22], that are translated into three general goals: to secure human existence, maintain society's productive potential, and preserve society's options for development and action. These goals are further concretized by a set of sustainability rules, such as the satisfaction of basic needs, equal access to education and information, the ability to provide for oneself, the sustainable use of renewable and nonrenewable resources, an adequate development of human and knowledge capital, maintenance of social resources, or the preservation of cultural heritage and cultural diversity. These rules constitute the core element of this concept. They describe guiding principles for action, defining a priori universally valid minimum requirements for a global sustainable development. Hence, they serve as basic orientation for future development and provide a comprehensive set of evaluation criteria (relating to countries, cities, societal sectors, strategies, and innovations). These general sustainability rules can be further concretized by sustainability indicators that are specific for the relevant application. A schematic representation of the architecture of the IHSC is shown in Figure 2.

The procedure to apply the IHSC included the following steps:

1. Selection of indicators of sustainability, following the following criteria:

(a) Validity: indicators should properly reflect how the sustainability of MSW management is affected by changes in indicator values.

(b) Data availability: information should be available in a time series if possible and access to these data should be feasible.

(c) Feasibility to define quantitative goals: this allows to evaluate if the targets have been achieved or not.

(d) Indicators should be easy to understand, even by people or working groups not associated with the field. 


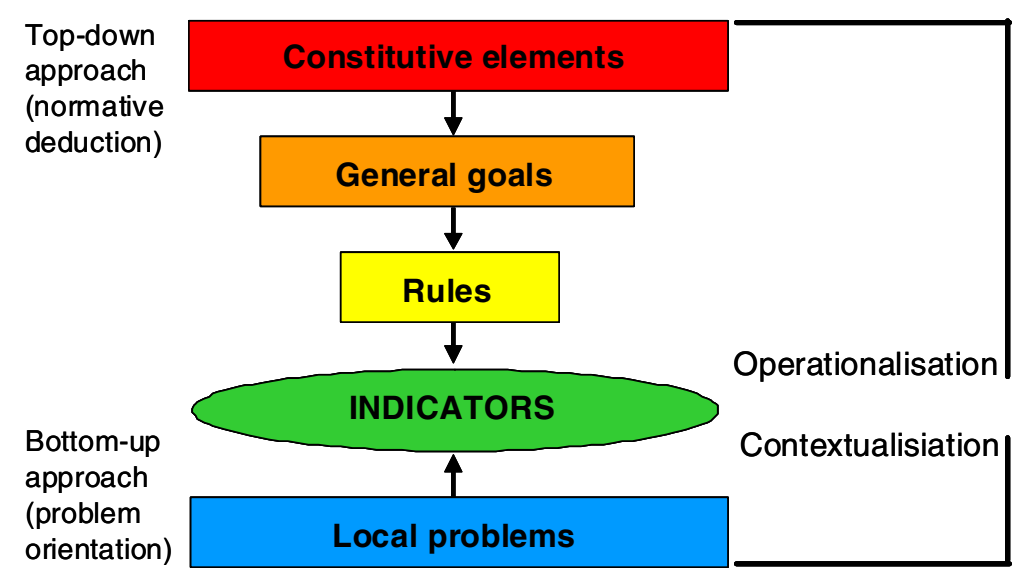

Figure 2 Architecture of the IHSC (adapted from [19]).

2. Selection of target values for selected indicators: after having selected a set of indicators as explained before, it is necessary to set favored target values. To select these values, a hierarchical approach was followed:

(a) Consideration of the existing Chilean framework, with respect to targets already set.

(b) For those indicators that the Chilean framework did not provide targets for, debates with scientists, politicians, public authorities, waste pickers, and other stakeholders were carried out.

(c) Finally, data from literature research regarding values established and achieved, at the international level, were used as references for target definition.

3. Identification of sustainability deficits: a comparison between the current indicator values and the favored target values (as explained in step 2) allowed identification of deficits threatening sustainability. The values of indicators for the current situation were determined in a previous work [23].

Table 1 shows the most relevant indicators, which have been selected on the basis of the criteria mentioned above.
The future explorative scenarios of MSW management are evaluated following the methodology explained in the 'Sustainability evaluation' section. The development of explorative scenarios is explained in the next subsection.

\section{Explorative scenarios}

One important question is how the management of MSW generated will look like in the future. If it is possible to have a look into the future, will it be possible to take actions today in order to improve that future? The scenario technique is a key concept for this type of prospective analysis, describing events and trends as they may evolve. This technique helps to support decision makers and policy makers to establish strategies for alternative futures [25]. Within the Risk Habitat Megacity Project, three explorative framework scenarios had been developed for the MRS: BAU, CR, and MI. These framework scenarios served as a basis for the establishment of specific scenarios in the field of MSW management in MRS. The framework scenarios are characterized by different driving forces for future development; as a consequence, the three scenarios, at the most general level, show differences in economic development (e.g., the increase of the GDP), institutional framework/ governance (e.g., market or state influence), demographics

Table 1 Selected indicators to evaluate MSW management in Santiago de Chile (adapted from [24])

\begin{tabular}{|c|c|}
\hline Waste management guideline & Indicator \\
\hline \multirow[t]{2}{*}{ Maintaining the regeneration capacity of natural systems } & $\begin{array}{l}\text { Quantity of pre-treated mixed waste to reduce biodegradable content, in } \\
\text { relation to total mixed waste }(\%)\end{array}$ \\
\hline & $\begin{array}{l}\text { Greenhouse gas emissions associated with MSW management }(\mathrm{kg} \mathrm{CO} \text { zeq } \\
\text { person }^{-1} \text { year }^{-1} \text { ) }\end{array}$ \\
\hline Frugal use of renewable and nonrenewable resources & Waste fraction recovered as material or energy (\%) \\
\hline \multirow{2}{*}{$\begin{array}{l}\text { Organization of the waste management system at justifiable overall } \\
\text { economic costs for a fairer development }\end{array}$} & Fraction of gross domestic product spent on MSW management (\%) \\
\hline & Income level of informal workers in relation to minimum wage (\%) \\
\hline
\end{tabular}


(e.g., population development), technological development (e.g., which technology), societal value system, and education.

The BAU scenario is characterized by a consuming culture. Environmental laws are weak and flexible. The political aim is to achieve waste recovery targets by improving recycling and biological treatment. New, tougher climate change mitigation policies push for the use of landfill gas as a renewable energy source. Technological advances encourage the application of alternative treatment technologies for the biogenic fraction of the residues. Technology developments have improved the efficiency of landfill gas collection, contributing to an increase in the share of renewable energies in the electricity network. With help of the civil society and nongovernmental organizations (NGOs), new recycling programs with participation of the waste pickers are developed. However, the informal waste sector is only partially integrated into the formal waste system.

The $C R$ scenario is characterized by high emphasis on social values. Environmental laws and targets are established. Waste recovery targets are achieved by improving recycling and biological treatment and increasing the amount of waste pre-treated. New, tougher climate change mitigation policies have promoted the collection and use of landfill gas as a renewable energy source.

The influence of NGOs on waste management is relevant, in particular promoting recycling, source separation, and recognition of the informal sector. The organization and efficiency of the informal sector has improved noticeably. Community organizations play an important role in the collection of recyclables. The amount of people working in the informal sector has decreased in number due to poverty reduction. However, the quality of their work has increased. They have formed strong alliances and engage in collection of segregated materials and further processing in stock centers.

The MI scenario is characterized by a consuming culture. Environmental laws are weak and flexible and are influenced by private interests and markets. The driving factor to recover valuable materials and energy from waste is given only by the economical profit.

Publicly organized recycling systems, including biological treatment, are almost nonexistent. Recycling takes place only voluntarily by drop-off systems. The role of the public sector in recycling is inexistent, and they do not have any interest in working together with the informal sector. Private production companies might show some interest in working together with the informal sector as a way to recover secondary raw materials at low costs.

The final definition of the MSW management scenarios was carried out in close cooperation with Chilean investigators, consultants, and government experts in order to develop technically and economically feasible alternatives for the city for the year 2030. In order to completely operationalize the explorative scenarios, it is necessary to determine the amount of waste generated as well as the treatment technologies to be used. The methods used for this are explained in the following subsections.

\section{Waste generation \\ $B A U$ scenario}

The GDP of a country strongly correlates to its economic prosperity, i.e., the standard of living of its population. A higher standard of living gives rise to higher consumption of products and goods and hence to an increase in waste production. As a consequence, there is a correlation between the GDP and the amount of waste produced [2]. The approach used in this research assumes that total MSW production up to now is the sum of waste landfilled and waste recovered because so far there is no waste treatment in MRS. Data for the MSW disposed of and MSW recycled and thus also data for the total production of waste were available for the years 1995 to 2007 [26,27]. From these data, the following correlations between GDP (based on purchasing power parity per capita) and amount of MSW production were derived and applied for MSW production until the year 2030, taking into consideration the development of the GDP given in the framework scenarios:

$$
\begin{aligned}
& M_{\mathrm{BAU}}=M_{L \mathrm{BAU}}+M_{R-\mathrm{BAU}}, \\
& M_{L B A U}=0.0294 \times \mathrm{GDP}^{0.3607}, \\
& M_{R-\mathrm{BAU}}=2.6473 \times 10^{-5} \times \mathrm{GDP}-0.1908,
\end{aligned}
$$

where

- $M_{\mathrm{BAU}}$ is the flux of MSW in the BAU scenario (kg.person ${ }^{-1}$ day $^{-1}$ ).

- $M_{\mathrm{LBAU}}$ is the flux of MSW landfilled (kg.person ${ }^{-1}$ day $^{-1}$ ).

- GDP is the gross domestic product $\left(\$ 2009\right.$ person $^{-1}$ year $\left.^{-1}\right)$.

- $M_{\mathrm{R}-\mathrm{BAU}}$ is the flux of MSW recovered (kg.person ${ }^{-1}$ day $^{-1}$ ).

\section{$C R$ and $M I$ scenarios}

A literature research allowed the identification of variables, other than GDP, that have an effect on the quantity of MSW generated. These variables are urbanization processes, household size, household income, and years spent in education, which differ in the three scenarios. To estimate the influence of these variables on the production of MSW in the CR and MI scenarios (in comparison to the BAU scenario), the following approach was used: 


$$
M_{i}=M_{\mathrm{GDP}, i} \times\left(a_{i} \times b_{i} \times c_{i} \times d_{i}\right),
$$

where

- $M_{i}$ is the flux of MSW in scenario $i\left(\mathrm{~kg}\right.$ person ${ }^{-1}$ day $\left.^{-1}\right)$.

- $M_{\mathrm{GDP}, i}$ is the flux of MSW in scenario $i$ calculated as a function of GDP in scenario $i$.

- $a_{i}$ is the parameter considering the relation between the amount of people living in the urban area and that in the rural area of MRS in scenario $i$, in comparison to scenario BAU (urbanization process).

- $b_{i}$ is the parameter considering the change of household size between scenario $i$ and BAU.

- $c_{i}$ is the parameter considering the change of household income between scenario $i$ and BAU.

- $d_{i}$ is the parameter considering the change of years of schooling between scenario $i$ and BAU.

The $M_{\mathrm{GDP}}$ to be used in Equation 4 is calculated as follows:

$$
\begin{aligned}
M_{\mathrm{GDP}, i}= & 0.0294 \times \mathrm{GDP}_{i}^{0.367}+2.6473 \times 10^{-5} \\
& \times \mathrm{GDP}_{i}-0.1908
\end{aligned}
$$

where GDP again is the gross domestic product in scenario $i$.

- Urbanization processes (factor $a_{i}$ ): in several studies [28-30], a positive correlation between the degree of urbanization and waste generation was found, whereas more densely populated areas (urban areas) are producing more waste per capita than rural areas and that MSW production in cities can be twice as high as that in rural areas. The degree of urbanization also affects indirectly waste generation due to a change in consumption patterns. For this study, it was assumed that a doubling of the share of people living in urban areas (compared to the BAU scenario) would lead to an increase in the production of MSW per capita by $30 \%$.

- Household size: larger households produce less waste per capita than smaller ones [28,30-33]. It is assumed that a doubling in the household size (compared to the BAU scenario) would lead to a decrease in the production of MSW per capita by $60 \%$.

- Household income: more affluent households are more likely to produce larger quantities of waste than the less affluent ones [28-31,33-36]. Additionally, income and MSW production are linked to some extent, but at a certain level of income, they become delinked. The turning point occurs at very high levels of value added per capita [33]. It is assumed that a doubling in household income (compared to the BAU scenario) would lead to an increase of $80 \%$ in the production of MSW per capita.

- Years spent in education: households with only primary education produce more waste than those belonging to professional levels [33]. However, not much research has been conducted in this area. For this reason, it was assumed that a doubling in the years spent in education (compared to the BAU scenario) would decrease MSW production per capita by $20 \%$.

For the calculation of parameters $a_{i}$ to $d_{i}$, (named as $\left.g_{i}\right)$, a linear correlation was used:

$$
g_{i}=100 \%+\Delta g_{\mathrm{BAU}-i} \times \mathrm{CF}_{g},
$$

where

- $g_{i}$ are the parameters $a$ to $d$, for scenario $i$.

- $\Delta g_{\mathrm{BAU}-i}$ is the variation between the BAU scenario and scenario $i$, for parameters $g$.

- $\mathrm{CF}_{g}$ is the correction factor for parameters $g$.

Table 2 summarizes the results of Equation 6 for each parameter $a$ to $d$. The correction factor (CF) is directly taken from the overall framework scenarios, developed by the Risk Habitat Megacity Project [18].

\section{Selection of MSW management technologies for the different scenarios}

Each scenario is defined by storylines and specific framework conditions. Based on these, it was possible to develop a general waste mass flow defining the different waste treatment options to be applied in each scenario; however, for each of these treatment options, different technologies exist.

The choice of which technology can be applied depends on the specific scenario because each technology was evaluated and compared by means of variables, including technical, environmental, and economic aspects, but the weight importance given to each aspect differs in each scenario, as shown in Table 3.

Variables used in the evaluation include:

\section{Technical aspects}

(a) Quantity of residual waste sent to landfill after treatment

(b) Quantity of compost produced

(c) Quantity of metals recovered

(d) Quantity of energy recovered 
Table 2 Correction factors as used in the determination of waste generation for alternative scenarios (own elaboration)

\begin{tabular}{|c|c|c|c|c|c|}
\hline & \multirow{2}{*}{$\begin{array}{l}\text { CF } \\
\text { (\%) }\end{array}$} & \multicolumn{2}{|c|}{$\Delta g$} & \multicolumn{2}{|c|}{9} \\
\hline & & $\begin{array}{l}\text { Collective Responsibility } \\
\text { (\%) }\end{array}$ & $\begin{array}{c}\text { Market Individualism } \\
(\%)\end{array}$ & $\begin{array}{l}\text { Collective Responsibility } \\
\text { (\%) }\end{array}$ & $\begin{array}{c}\text { Market Individualism } \\
(\%)\end{array}$ \\
\hline Urban population change & +30 & -8.2 & 2.5 & 97.5 & 100.7 \\
\hline Household size & -60 & 6.7 & -6.7 & 96.0 & 104.0 \\
\hline Household income (2030) & +80 & -2.4 & -3.6 & 98.1 & 97.1 \\
\hline Years of schooling & -20 & 3.4 & -3.4 & 99.3 & 100.7 \\
\hline
\end{tabular}

\section{Environmental aspects}

(a) Net greenhouse gases emitted related to the facility

\section{Economic aspects}
(a) Capital costs
(b) Gross production costs
(c) Revenues

Characteristics of a modern plant were used to describe each technology, which included composting vs. anaerobic digestion for biological treatment and four technologies for energy recovery:

1. Incineration plant exporting electricity

2. Mechanical biological treatment plant, where metals were separated and the remaining waste was:

(a) Sorted into a biogenic component to be anaerobically digested and a fraction which is sent to landfills

(b) Biodried to produce a refuse-derived fuel (RDF) which is co-combusted in cement kilns

(c) Sorted into an organic component to be anaerobically digested and a fraction which is used to produce a RDF which is co-combusted in cement kilns

The final decision for selecting particular technologies in BAU, CR, and MI was a result of workshops, where scientists and stakeholders came together in Chile. This allowed creating plausible scenarios for the Chilean reality, avoiding only the transfer of technologies from

Table 3 Weight assigned to decision aspects used in the technology selection (own elaboration)

\begin{tabular}{llll}
\hline & Economic & Technical & Environmental \\
\hline BAU & 3 & 2 & 1 \\
$\mathrm{CR}$ & 2 & 1 & 3 \\
$\mathrm{MI}$ & 3 & 2 & 1 \\
\hline
\end{tabular}

Europe to Latin America. In addition, during these workshops, it was also discussed which amount of MSW should be assigned to each of the technologies in 2030 .

\section{Calculation of energy production from MSW}

In all the scenarios, it is assumed that landfill gas is collected and used for power generation; therefore, the equations used for the calculations are shown. The timedependent production of landfill gas was calculated by the following formulas:

$$
\begin{aligned}
& G_{t}=G_{\text {total }} \times\left(k \times e^{-k t}\right) \times M_{\text {landfilled }} \\
& G_{\text {total }}=1.868 \times c_{\text {org }} \times(0.014 T+0.28)
\end{aligned}
$$

where

- $G_{t}$ is the landfill gas production at year $t$ after deposition $\left(\mathrm{Nm}^{3}\right)$.

- $G_{\text {total }}$ is the total landfill gas production potential $\left(\mathrm{Nm}^{3} \mathrm{Mg}_{\text {waste }}^{-1}\right)$.

- $k$ is the generation rate constant $\left(\right.$ year $\left.^{-1}\right)$.

- $c_{\text {org }}$ is the total biodegradable carbon content $(\mathrm{kg}$ carbon $\mathrm{Mg}_{\text {waste }}^{-1}$ ).

- $T$ is the temperature within the landfill $\left({ }^{\circ} \mathrm{C}\right)$.

Equation 8 is the formula of Tabasaran and Rettenberger [37]. Because of the lack of measurements taken at landfills in MRS, the method of [38] was used to calculate the landfill gas generation rate, resulting in a value for $k$ of 0.022 year $^{-1}$, which means a half-life of about 33 years (for the calculation, see also [39]). For $T$, a value of $39^{\circ} \mathrm{C}$ was used. $c_{\text {org }}$ was calculated on the basis of the composition of MSW in MRS [40].

\section{Energy production from biogas/landfill gas}

The energy generated with biogas and landfill gas was calculated as follows:

$$
Q_{P-B}^{*}=V_{\text {biogas }} \times x_{\mathrm{CH} 4} \times \mathrm{CV}_{\mathrm{CH} 4} \times \varepsilon_{e} \times M^{\mathrm{AD}},
$$

where 
- $Q_{P-B}^{*}$ is the flow of energy generated from biowaste $\left(\mathrm{MJ}\right.$ year $\left.^{-1}\right)$.

- $V_{\text {biogas }}$ is the volume of biogas/landfill gas produced $\left(\mathrm{m}^{3}\right)$.

- $x_{\mathrm{CH} 4}$ is the volumetric fraction of methane in biogas.

- $\mathrm{CV}_{\mathrm{CH} 4}$ is the calorific value of methane ( $\mathrm{MJ} \mathrm{m}^{-3}$ ).

- $\varepsilon_{\mathrm{e}}$ is the energy (thermal or electrical) generation efficiency.

- $M^{\mathrm{AD}}$ is the flow to anaerobic digestion process $(\mathrm{Mg}$ year $^{-1}$ ).

The calculations for the landfill gas were based on the following assumptions:

- Content of $\mathrm{CH}_{4}$ in landfill gas $x_{\mathrm{CH} 4}(55 \%)$

- Collection efficiency (25\%)

- Heating value of $\mathrm{CH}_{4}\left(37.8 \mathrm{MJ} \mathrm{Nm}{ }^{-3}\right)$

- Efficiency of electricity production (30\%)

The calculations for the biogas from anaerobic digestion were based on the following assumptions:

- Biogas yield (10\% to $16 \%)$

- $V_{\text {biogas }}\left(0.38 \mathrm{~m}^{3}\right.$ biogas $\mathrm{kg}$ organic dry matter $\left.^{-1}\right)$

- Content of $\mathrm{CH}_{4}$ in biogas gas (58\%)

- Heating value of $\left.\mathrm{CH}_{4}(37.8 \mathrm{M}) \mathrm{Nm}^{-3}\right)$

- Net efficiency of electricity production (21\%)

\section{Energy production from RDF}

RDF is often used as a substitute for conventional fuels in cement kilns. RDF can also be used in coal-fired power plants as a substitute for a part of the coal. A heating value of $14 \mathrm{MJ} \mathrm{kg}^{-1}$ was used for the calculations.

\section{Results and discussion}

Waste generation and waste collection

Table 4 shows a summary of MSW generation for the base situation (2007) as well as for the future scenarios in 2030. The quantity of MSW produced per capita increased from $1.2 \mathrm{~kg}$ in 2007 to $1.9 \mathrm{~kg}$ in the BAU scenario, to $1.8 \mathrm{~kg}$ in the CR scenario, and to $2.0 \mathrm{~kg}$ in the MI scenario. Total waste production increases from 2.9

\begin{tabular}{|c|c|c|c|}
\hline & $\begin{array}{l}\text { Population } \\
\text { (million) }\end{array}$ & $\begin{array}{l}\text { MSW flow } \\
\text { (million Mg) }\end{array}$ & $\begin{array}{l}\text { MSW flux } \\
\left(\mathbf{k g ~ p e r s o n}^{-1}\right. \\
\left.\text { day }^{-1}\right)\end{array}$ \\
\hline Base situation (2007) & 6.7 & 2.9 & 1.2 \\
\hline Business as Usual & 8.0 & 5.6 & 1.9 \\
\hline Collective Responsibility & 7.6 & 4.9 & 1.8 \\
\hline Market Individualism & 8.3 & 6.1 & 2.0 \\
\hline
\end{tabular}

million $\mathrm{Mg}$ in 2007 to 8.0 million $\mathrm{Mg}$ (BAU), to 7.6 million $\mathrm{Mg}(\mathrm{CR})$, and to 8.3 million $\mathrm{Mg}(\mathrm{MI})$.

Figures 3, 4, and 5 show the mass flow diagram for the BAU, CR, and MI scenarios, respectively. In the BAU scenario, a fraction of about $70 \%$ of MSW is deposited in landfills, whereas the rest is diverted for the recovery of materials and energy. Anaerobic digestion was the selected technology for the treatment of the organic fraction of the waste. In the CR scenario, a fraction of $40 \%$ is sent to landfills without previous treatment, and the remainder is used for energy and material recovery. In this scenario, anaerobic digestion was also selected for the treatment of the biowaste. Additionally, MBT with anaerobic digestion and RDF production was used to pre-treat the waste arriving at the landfills. In the MI scenario, a total fraction of $80 \%$ is sent directly to landfills and only $20 \%$ is used for recovery.

\section{Energy recovery}

In 2010, electricity demand in MRS was about $17 \mathrm{TWh}$, while electricity generation in MRS was only about 25\% of this value; therefore, $75 \%$ had to be 'imported' via the electricity grid [14]. About $50 \%$ of electricity generation in MRS comes from hydropower plants. Due to climate change, it is expected that temperatures will increase, while rainfall rates will decrease, resulting in a decrease of the stream flow in the rivers and therefore possibly in a decrease of electricity production from hydropower plants. Moreover, it is expected that energy demand will rise due to rise of population and standards of living. In this section, it is shown how different fractions of MSW and landfill gas might contribute to the energy supply in MRS in the future scenarios.

In the BAU scenario, energy recovery from MSW is achieved by the installation of anaerobic digestion plants to produce biogas. In addition, landfill gas at the three existing landfills is collected and used for electricity generation.

In the CR scenario, in addition to the installation of anaerobic digestion plants to produce biogas, it was considered that the biological treatment process of the MBT plants consists also anaerobic treatment. Many of these plants have even been built $[41,42]$, and they are gaining importance in countries where there is still disapproval against incineration but where there is interest in increasing the fraction of the amount of energy produced from waste [41].

In the MI scenario, there is a lack of incentives promoting alternative waste treatment technologies; therefore, only mechanical sorting processes are implemented. In this scenario, there are no new technologies for the recovery of energy from waste, and only landfill gas is used as a renewable energy source. 


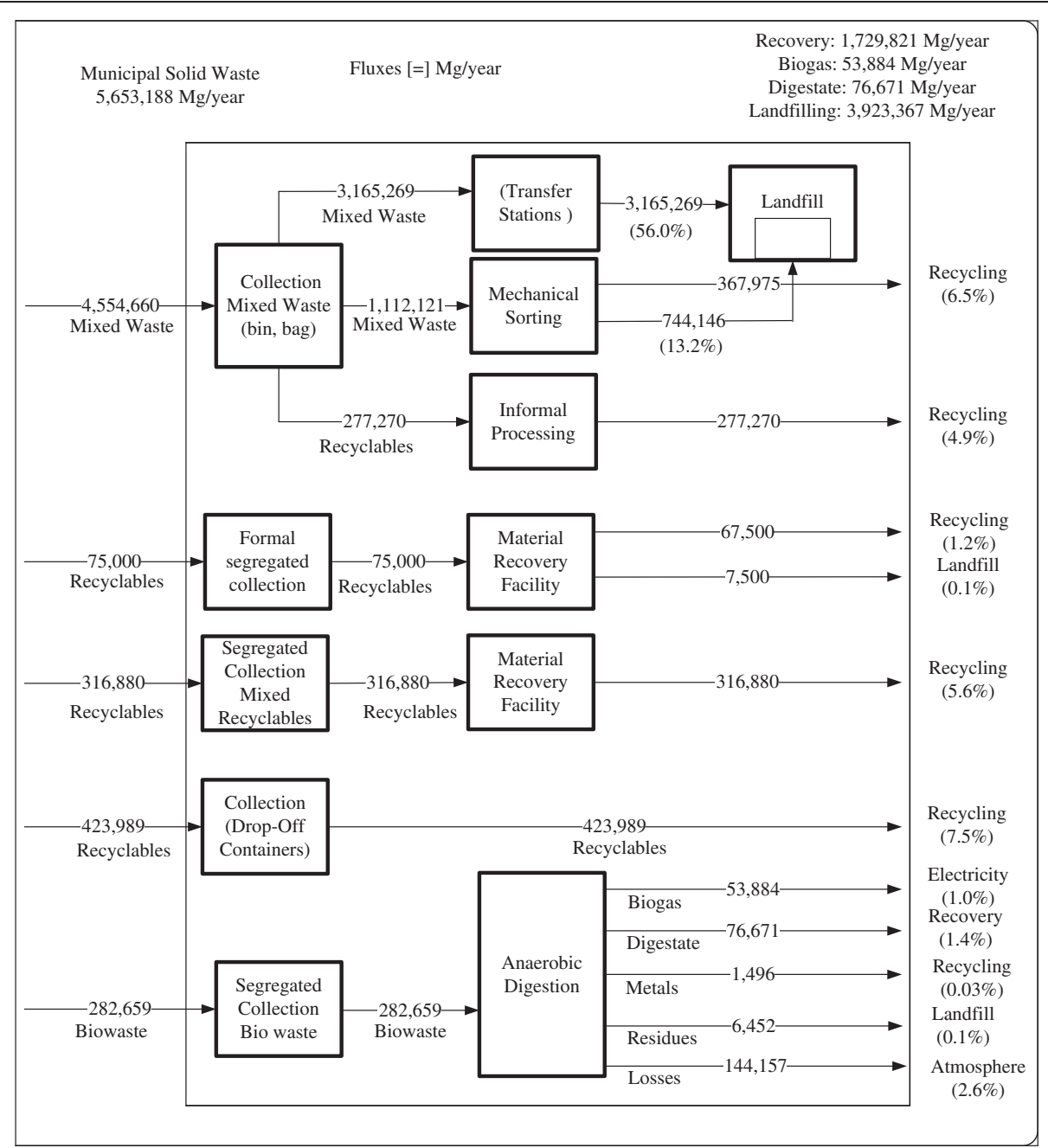

Figure 3 Municipal solid waste mass flow diagram - BAU scenario year 2030 (own elaboration).

Table 5 gives an overview of energy production within the different scenarios. Total electricity consumption in MRS was about 17 TWh. Therefore, the energy generation from MSW is only of minor importance (about $6 \%$ compared to electricity consumption in the same year). On the other side, taking into consideration only the amount of energy produced in MRS (25\% of total energy consumption, which means 4.25 TWh), energy generation from MSW might contribute with nearly $25 \%$.

Worldwide, there is a general agreement that global climate change is, to a large extent, caused by anthropogenic $\mathrm{CO}_{2}$ emissions. It is necessary to reduce the $\mathrm{CO}_{2}$ footprint of human activities. Therefore, even though the contribution to total energy consumption is relatively low in the three scenarios, it is important to

Table 5 Energy recovery from waste (own elaboration)

\begin{tabular}{|c|c|c|c|c|c|c|c|c|c|c|c|c|}
\hline & \multicolumn{3}{|c|}{$\begin{array}{l}\text { Biogas/landfill gas } \\
\text { collected } \\
\text { (million } \mathrm{Nm}^{3} \text { year }^{-1} \text { ) }\end{array}$} & \multicolumn{3}{|c|}{$\begin{array}{l}\text { Net energy } \\
\text { production } \\
\left(\text { GWh year }{ }^{-1}\right)\end{array}$} & \multicolumn{3}{|c|}{$\begin{array}{l}\text { Alternative fuel (RDF) } \\
\text { production } \\
\text { (thousand } \mathrm{Mg} \text { ) }\end{array}$} & \multicolumn{3}{|c|}{$\begin{array}{l}\text { Thermal recovery (substitution of } \\
\text { conventional fuels) } \\
\text { (GWh year }{ }^{-1} \text { ) }\end{array}$} \\
\hline & BAU & CR & $\mathrm{MI}$ & $\mathrm{BAU}$ & CR & MI & BAU & CR & MI & BAU & CR & MI \\
\hline Anaerobic digestion & 47 & 65 & - & 63 & 88 & - & - & - & - & - & - & - \\
\hline Anaerobic digestion in MBT plants & - & 37 & - & - & 44 & - & - & - & - & - & - & - \\
\hline RDF from MBT & - & - & - & - & - & - & - & 265 & - & - & 1,057 & - \\
\hline Landfill gas collected (2030) & 440 & 377 & 489 & 890 & 763 & 989 & - & & - & - & - & - \\
\hline
\end{tabular}




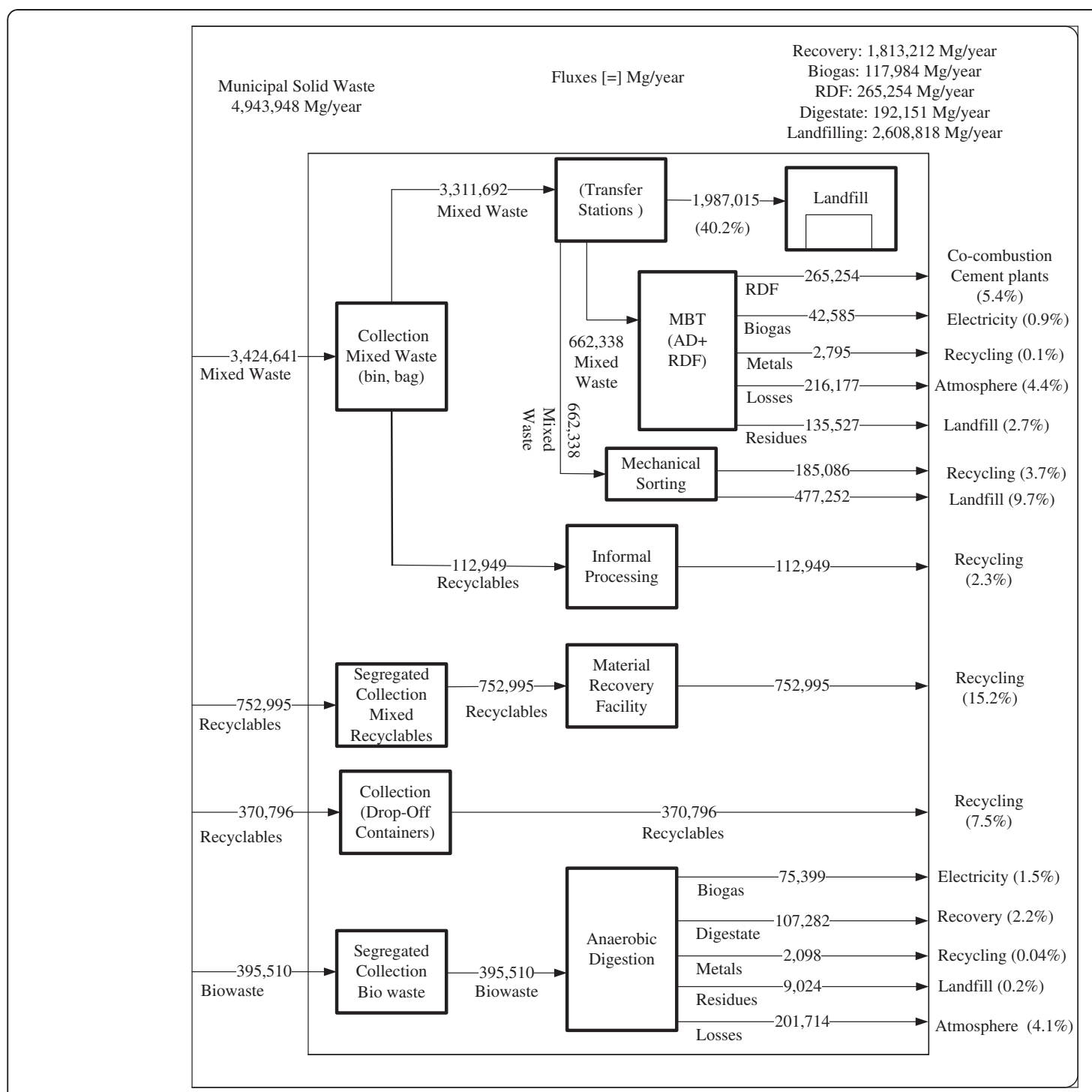

Figure 4 Municipal solid waste mass flow diagram - CR scenario year 2030 (own elaboration).

consider that landfill gas will form in any case; therefore, it does make sense to use it as a renewable source of energy, instead of releasing it into the atmosphere. The latter would increase the emissions of greenhouse gases due to the $\mathrm{CH}_{4}$ produced being 21 times more potent than $\mathrm{CO}_{2}$. On the other side, the production of RDF and its use as a secondary fuel in cement kilns might contribute to about $25 \%$ to total energy consumption for cement production in MRS (for the year 2007).

\section{Evaluation of MSW management with respect to sustainability}

The management of MSW in MRS in the different scenarios was evaluated on the basis of different

Table 6 Most relevant sustainability indicators for the different scenarios (own elaboration)

\begin{tabular}{|c|c|c|c|c|c|}
\hline Indicator & 2007 & Target & BAU & CR & MI \\
\hline Waste fraction recovered as material or energy (\%) & 13.9 & 36 & 31 & 43 & 20 \\
\hline Income level of informal workers in relation to individual household income (\%) & 76 & 100 & 113 & 154 & - \\
\hline Amount of mixed waste pre-treated to reduce biodegradable content in relation to total mixed waste (\%) & 0 & 50 & 0 & 19 & 0 \\
\hline Greenhouse gases emitted during waste management $\left(\mathrm{kgCO}_{2 \text { eq }}\right.$ person ${ }^{-1}$ year $\left.{ }^{-1}\right)$ & 143 & 71 & 235 & 153 & 296 \\
\hline Costs of MSW management in relation to GDP (\%) & 0.22 & 0.30 & 0.16 & 0.17 & 0.16 \\
\hline
\end{tabular}




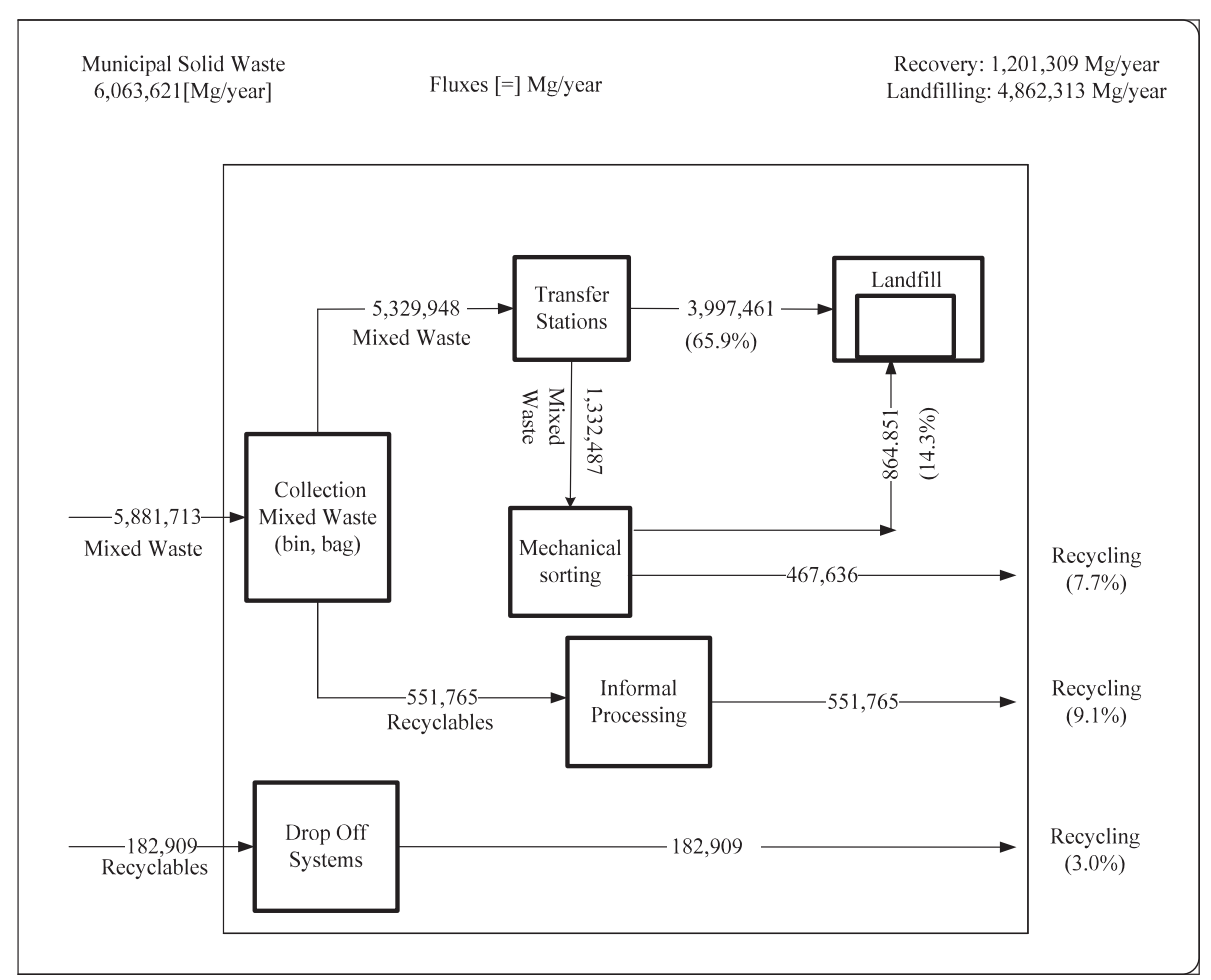

Figure 5 Municipal solid waste mass flow diagram - MI scenario year 2030 (own elaboration).

sustainability indicators and on their associated target values, as explained in the 'Sustainability evaluation' section (see Table 6). These target values represent a commonly agreed goal, which should be achieved in the future in order to fulfill the principles of sustainability. Indicators and target values were defined together with Chilean investigators, consultants, and government experts during several workshops within this study.

The improvement shown in the BAU scenario for the amount of waste recovered (31\%) is attributed to the installation of mechanical sorting plants and segregated collection of biodegradable waste and recyclables through organized primary waste collectors, in addition to energy recovery from landfill gas and biogas. The organization of the informal workers is also reflected in an improvement of their income level.

In the CR scenario, the recovered quantity of MSW $(43 \%)$ is higher than the target $(36 \%)$ because the implemented measures are based on several different collection and treatment systems: segregated collection of biodegradable waste, inclusion of primary collectors into collection systems, participation of citizens in dropoff systems, and recovery of the energy from MSW and from landfill gas (Figure 4). Nevertheless, greenhouse gas emissions are still far away from the target value. This fact can be mainly attributed to the still large amount of organics being disposed of at landfill sites.
The MI scenario shows large deficits in almost all the indicators. It must be noticed that even though this scenario presents the largest processing capacity for the mechanical sorting plants, the recovery value in this scenario is the lowest. One of the goals of MSW management should be the conservation of resources [16], which in general is more related with the recovery of materials (mechanical sorting plants in this case), but of equal importance should be energy recovery from waste. However, the intrinsic characteristics of this scenario [18] did not allow the implementation of these techniques because all environmental measures are moved by private markets and there are no laws forcing the implementation of energy recovery. Neither the informal waste pickers is included into the management system. Therefore, they were not able to improve their working capacity and working conditions.

In the three scenarios, there is still a large fraction of mixed MSW disposed of at landfills. This is related with high emissions of greenhouse gases due to the decomposition of the biogenic fraction. The emissions of greenhouse gases contribute to climate change. Energy recovery from the biogenic fraction of the MSW might contribute to mitigate this phenomenon because the $\mathrm{CO}_{2}$ emitted from the thermal conversion of this fraction is neutral for the climate. Additionally, it contributes to the conservation of resources by substitution of 
other combustibles. If the landfill gas is not used to produce electricity, but only collected and flared, the GHG emissions in per capita terms increases by $13 \%, 17 \%$, and $11 \%$ in the BAU, CR, and MI scenarios, respectively. Therefore, the substitution of fossil fuels by landfill gas in electricity generation plays a significant role in the reduction of GHG emission, in particular in the CR scenario.

The results also imply that the informal waste pickers should be integrated in separate collection of recyclables (BAU and CR scenarios). For biodegradable waste, a good treatment option is anaerobic digestion with utilization of the biogas produced (BAU and CR scenarios) for energy generation.

In the three scenarios, incineration of MSW was not taken into consideration because during debates with Chilean experts, it was concluded that this will not be an option for the next 20 years due to high costs of incineration (US\$110 to US $\$ 160 \mathrm{Mg}^{-1}$ ) [41] compared with current costs of waste management in MRS (collection costs US $\$ 26 \mathrm{Mg}^{-1}$, landfilling costs US $\$ 11 \mathrm{Mg}^{-1}$ ) [43].

The results of the sustainability evaluation show that each explorative scenario presents deficits; even in the CR scenario, not all the targets can be reached. It is clear that the integration of other factors is still required in order to improve the sustainability of the MSW management system. Technology is only one part of the whole structure. A sustainable system requires the incorporation of government policy and regulations, responsible consumption patterns, and adequate cost calculations and education, in addition to technological developments.

Moreover, it is necessary to take advantage of the subsystems already working within the whole system. Two important examples in this case are the integration of the informal waste pickers, which already have an effective network in MRS, and the use of landfill gas as a renewable energy source for energy generation.

The three scenarios did not look to identify a best solution but investigated possible futures in MRS. The results should help decision makers to visualize how the future might look like and take appropriate measures in time. The authorities of MRS should start now to plan and construct the appropriate MSW treatment plants and start to implement the respective measures for the MSW management that they want to achieve in 2030 . The model presented here could also be used, with the respective adaptations, in other Latin American megacities in order to determine the adequacy of the MSW management there.

\section{Conclusions}

In this study, two key tools were used in order to evaluate the sustainability of different MSW management systems and to describe its development in the next 20 years. On the first place, the ISHC was used as a tool to evaluate the sustainability of the MSW management of Santiago de Chile in the future. This concept, which has also been applied to other fields of application within the Risk Habitat Megacity Project (such as water management and energy demand and supply), proved to be adequate because it provides a methodology to select indicators, determine their current (and future) value, and define desirable target values, and by comparison of both (actual vs. desired), it was possible to evaluate the actual MSW system as well as future MSW management options with respect to whether there will be an increase in sustainability or not.

On the other hand, in order to define how the MSW management of Santiago de Chile will look like in the future, the scenario technique was used. Explorative scenarios were developed, giving an insight about which probable MSW management trends will follow in accordance with possible political, economical, and environmental decisions taken today.

The BAU scenario was characterized by current trends and policies. The CR scenario was characterized by stronger emphasis on social values and implementation of tougher environmental regulations. The MI scenario was characterized by a materialistic culture, with a strong private influence in all political and economic areas. The results showed that MSW generation increased in total and in per capita terms in the three scenarios, exceeding the target value chosen $\left(1.6 \mathrm{~kg}\right.$ (person.day) $\left.{ }^{-1}\right)$. In the CR scenario, a recovery value of $43 \%$ was obtained (target value was $36 \%$ ) through public-private partnerships (drop-off systems), private investments (as in the case of sorting plants at transfer stations), and organizational improvements of the informal waste sector. In addition, there is a large contribution to sustainability by the recovery of biowaste and subsequent energy generation from biogas and RDF.

In all three scenarios, landfill sites contribute to methane emissions in MRS and thus have a share in climate change. The improvement in efficiency of landfill gas collection systems results in a reduction of these emissions in all three cases. The landfill gas collected is used as a renewable energy source for electricity generation, thereby reducing $\mathrm{CO}_{2}$ emissions from conventional power stations fired by fossil fuels.

Even though the share of electricity production by MSW fractions and biogas in the three scenarios is relatively low, they are accompanied by positive aspects such as the reduction of methane emissions on one side and favoring energy supply within the MRS from renewable energies on the other side. All three scenarios show some sustainability deficits. Furthermore, the results obtained show that an integration of several factors is required in waste management systems. Technology is only one part of the whole solid waste management structure, and it cannot solve alone all the associated problems and avoid its associated negative impacts. A 
more or less sustainable system requires the incorporation of government policy and regulations, sustainable consumption patterns, adequate cost calculations, and education, in addition to technological development.

\section{Endnote}

${ }^{a}$ For more information about the Risk Habitat Megacity Project, see http://www.ufz.de/risk-habitat-megacity/.

\author{
Abbreviations \\ BAU: Business as Usual scenario; CR: Collective Responsibility scenario; \\ GHG: green house gas emissions; IHSC: Integrative Helmholtz Sustainability \\ Concept; MBT: mechanical biological treatment; MI: Market Individualism \\ scenario; MRS: Metropolitan Region of Santiago de Chile; MSW: municipal \\ solid waste; RDF: refuse-derived fuel.
}

\section{Competing interests}

The authors declare that they have no competing interests.

\section{Authors' contributions}

The article presents some of the main results of the work done within the application field of 'MSW management in the Metropolitan Region of Santiago de Chile' within the context of the 'Risk Habitat Megacity Project' as well as within the doctoral thesis of Tahnee González Martínez. All authors contributed to all parts of the article. All authors read and approved the final manuscript.

\section{Acknowledgements}

This study was supported by the Initiative and Networking Fund of the Helmholtz Association. Additionally, funding for the foreign stay in Santiago de Chile was given by the Karlsruhe House of Young Scientists.

\section{Author details}

${ }^{1}$ Linde AG Engineering Division, Dr.-Carl-von-Linde-Str. 6-14, Pullach, München 82049, Germany. ${ }^{2}$ Karlsruhe Institute of Technology, POB 3640, Karlsruhe 76021, Germany.

Received: 10 December 2012 Accepted: 12 December 2012 Published: 20 December 2012

\section{References}

1. Seifert $H$ (2006) Thermal waste treatment. Teaching and research in thermal waste treatment. Universität Stuttgart, Institut für Feuerungs- und Kraftwerkstechnik, Stuttgart

2. Vehlow J, Berfgeldt B, Visser HJM, Wilén C (2007) EU waste management strategy and the importance of biogenic waste. J Mater Cycles Waste 9:130-139

3. Friederich R, Jaron A, Schulz J (2011) Closed-loop waste management. Recovering wastes - conserving resources. Federal Ministry for the Environment, Nature Conservation and Nuclear Safety, Berlin

4. AGEB (AG Energiebilanzen e.V.) (2012) Energieverbrauch in Deutschland im Jahr 2011. AGEB, Berlin

5. Leipziger Institut für Energie GmbH (2012) Jahresprognose 2011 zur deutschlandweiten Stromerzeugung aus regenerativen Kraftwerken. Leipziger Institut für Energie GmbH, Leipzig

6. United Nations (2004) The state of the world's cities 2004/2005. Globalization and Urban Culture Settlements Program. UN-Habitat, London

7. Müller C (2007) Anaerobic digestion of biodegradable solid waste in low and middle income countries. Eawag/Sandec, Dübendorf

8. Deutsche Gesellschaft für Technische Zusammenarbeit GTZ (2006) Prevención y Gestión Integral de Residuos Sólidos Urbanos. Experiencias de Nueve Años de Cooperación Tecnica Alemana en Mexico. Deutsche Gesellschaft füt Technische Zusammenarbeit (GTZ) GmbH, Eschborn

9. Münnich K, Mahler CF, Fricke K (2006) Pilot project of mechanical biological treatment of waste in Brazil. Waste Manag 26:150-157

10. Münnich K (2009) Wissenschaftliche Begleitung des Pilotprojektes zur Anwendung des FABER AMBRA Verfahrens zur mechanisch-biologischen
Abfallbehandlung in Villa Alemana, Provinz Marga-Marga/Chile, Final Report. TU Braunschweig, Abfall- und Ressourcenwirtschaft, Braunschweig

11. Medina M (2000) Scavenger cooperatives in Asia and Latin America. Resour Conserv Recy 31(1):51-69

12. Medina M (2008) The informal recycling sector in developing countries. Grid Lines 44. The World Bank and Public-Private Infrastructure Advisory Facility, Washington, D.C

13. Florisbela A, Astorga A (2006) La integración del sector informal en la gestión de los residuos sólidos urbanos, enfoque al sector de la chatarra (The integration of the informal sector in the MSW management, focus to the scrap sector). Deutsche Gesellschaft für Technische Zusammenarbeit $\mathrm{GmbH}$, Eschborn

14. Simon S, Stelzer V, Vargas L, Paredes G, Quintero A, Kopfmüller J (2012) Energy systems. In: Heinrichs D, Krellenberg K, Hansjürgens B, Martínez F (eds) Risk Habitat Megacity. Springer, New York, pp 183-205

15. Durandeau S (2010) La experiencia del Relleno Sanitario Loma Los Colorados en Captura de Biogás y Generación de Energía en el marco de proyectos MDL, Foro Latinoamericano del Carbono Santo Domingo - República Dominicana 13-15 Octubre 2010. http://www.latincarbon.com/2010/docs/presentations/ Day2/Sergio_Durandeau.pdf. Accessed 13 Dec 2012

16. Brunner PH, Fellner J (2007) Setting priorities for waste management strategies in developing countries. Waste Manag Res 25:234-240

17. Kopfmüller J, Brandl V, Jörissen J, Paetau M, Banse G, Coenen R, Grunwald A (2001) Nachhaltige Entwicklung integrativ betrachtet. Konstitutive Elemente, Regeln, Indikatoren. Global zukunftsfähige Entwicklung - Perspektiven für Deutschland. Edition Sigma, Berlin

18. Helmholtz Centre for Environmental Research (2010) How sustainable is Santiago de Chile? Risk Habitat Megacity research initiative. Helmholtz Centre for Environmental Research, Leipzig

19. Kopfmüller J, Lehn H, Heinrichs D, Krellenberg K, Nuissl H (2009) Die HGF Forschungsinitiative "Risk Habitat Megacity": Ziele, Ansatz, Fragestellungen. Technikfolgenabschätzung Theorie und Praxis 1:35-44

20. Barton JR, Kopfmüller J (2012) Sustainable urban development in Santiago de Chile: background - concept - challenges. In: Heinrichs D, Krellenberg K Hansjürgens B, Martínez F (eds) Risk Habitat Megacity. Springer, New York, pp 65-86

21. Kopfmüller J, Barton J, Salas A (2012) How sustainable is Santiago? In: Heinrichs D, Krellenberg K, Hansjürgens B, Martínez F (eds) Risk Habitat Megacity. Springer, New York, pp 305-326

22. Schultz J, Brand F, Kopfmüller J, Ott K (2008) Building a "theory of sustainable development": two salient conceptions within the German discourse. Int J Environ Sustain Dev 7(4):465-482

23. Bräutigam K-R, Gonzalez T, Seidl N, Seifert H, Szanto M (2008) Risk Habitat Megacity - waste management in Santiago de Chile. In: Ingeniera de residuos. Hacia una gestion sostenible. Proceedings I. Simposio Iberoamericano sobre Ingeniería de Residuos. REDISA 2008. Ingeniería de Saneamiento Ambiental. La Gestión Sostenible de los Residuos, Castellón, Spain, 24 July 2008. Universitat Jaume, Castelló de la Plana, p 125

24. Seidl N (2008) Auswahl und Analyse von Nachhaltigkeitsindikatoren für den Bereich Abfall für Santiago de Chile. Final Work Thesis, Universität KoblenzLandau and Karlsruhe Institute of Technology

25. Kosow H, Gaßner R (2008) Methods of future and scenario analysis. Overview, assessment, and selection criteria. Deutsches Institut für Entwicklungspolitik, Bonn

26. Environmental National Commission of Chile (CONAMA) (2009) Estadísticas de reciclaje año 1998-2007 en la Región Metropolitana (Recyclic statistics year 1998-2007). Hazardous Waste Management Division, Santiago de Chile

27. Secretaría Regional Ministerial de Salud Región Metropolitana (2008) Información Ambiental. Estadistica de residuos solidos dispuestos en rellenos sanitarios autorizados en la RM (MSW landfilled in the Metropolitan Region). http://www.seremisaludrm.cl/sitio/pag/residuos/ indexjs3residuoses001 p.asp. Accessed 13 Dec 2012

28. Cailas MD, Kerzee RG, Swager R, Anderson R (1993) Development and application of a comprehensive approach for estimating solid waste generation in Illinois: first phase results. University of Illinois, Champaign

29. Henricks SL (1994) Socio-economic determinants of solid waste generation and composition in Florida. M.S. Thesis, Duke University School of the Environment

30. Hockett DJ, Lober K (1995) Determinants of per capita municipal solid waste generation in the Southeastern United States. J Environ Manage 45(3):205-217 
31. Dennison GJ, Dodd VA, Whelan B (1996) A socio-economic based survey of household waste characteristics in the city of Dublin, Ireland - II. Waste quantities. Resour Conserv Recy 17:245-257

32. Jenkis R (1993) The economics of solid waste reduction: the impact of user fees. Edward Elgar, Cheltenham

33. Beigl P, Wassermann G, Schneider F, Salhofer S (2003) The use of life cycle assessment tool for the development of integrated waste management strategies for cities and regions with rapid growing economies. University of Natural Resources and Applied Life Sciences, Vienna

34. Ojeda S, Armijo C, Marquez M (2008) Household solid waste characterization by family socioeconomic profile as unit of analysis. Resour Conserv Recy 52(7):992-999

35. Orccosupa J (2002) Relationship among the per capita generation of household solid waste and socioeconomic variables. M.S. Thesis, Universidad Santiago de Chile, Santiago de Chile Province

36. Chang N, Pan Y, Huang S (1993) Time series forecasting of solid waste generation. J Resource Manag Tech 21:1-9

37. Tabasaran O, Rettenberger G (1987) Grundlagen zur Planung von Entgasungsanlagen. In: Hösel G, Schenkel W, Schurer H (eds) vol 3. Müll-Handbuch E. Schmidt, Berlin

38. Garg A, Achari G, Joshi R (2006) A model to estimate the methane generation rate constant in sanitary landfills using fuzzy synthetic evaluation. Waste Manag Res 24(4):363-375

39. González T (2011) Analysis of different municipal solid waste management systems for Santiago de Chile. Ph.D. Thesis, Universität Stuttgart

40. Bräutigam K-R, González T, Seifert H (2009) Landfill gas emissions from landfills in Santiago de Chile - strategies to reduce impact on local environment as well as on global climate. In: Escudero de Fonseca A (ed) La gestión sostenible de los residuos. II Simposio Iberoamericano de Ingeniería de Residuos, Barranquilla

41. Gerlagh T, Pfeiffer E (2009) Accomplishment from IEA Bioenergy Task 36: integrating energy recovery into solid waste management (2007-2009). International Energy Agency Bioenergy, Paris

42. Archer E, Baddeley A, Klein A, Schwager BA, Whiting K (2005) Mechanical biological treatment: a guide for decision makers, processes, policies and markets. Juniper Consultancy Services, Belfast

43. Godoy R, Ossadón P (2009) Risk Habitat Megacity: Residuos solidos domiciliarios - Region Metropolitana (MSW in the Metropolitan Region). B.S. Thesis, Universidad Católica de Valparaíso

doi:10.1186/2192-0567-2-24

Cite this article as: González Martínez et al:: The potential of a sustainable municipal waste management system for Santiago de Chile, including energy production from waste. Energy, Sustainability and Society 2012 2:24.

\section{Submit your manuscript to a SpringerOpen ${ }^{\odot}$ journal and benefit from:}

- Convenient online submission

- Rigorous peer review

- Immediate publication on acceptance

- Open access: articles freely available online

- High visibility within the field

- Retaining the copyright to your article

Submit your next manuscript at $\gg$ springeropen.com 